\title{
Trabalhando com o mito - leitura intertextual de Daniel 7 e das tradições de Leviathan e Behemoth em Apocalipse 13
}

\author{
José Adriano Filho*
}

\section{Resumo}

O Apocalipse de João contém diversas referências às Escrituras Judaicas e a outras tradições do mundo greco-romano, as quais são constantemente recriadas e ressignificadas no desenvolvimento do livro. Considerando que um texto é uma voz que dialoga com outros textos, mas também funciona como eco das vozes de seu tempo, da história de um grupo social, de seus valores e crenças, este artigo procura demonstrar as redes de intertextualidade presentes em Apocalipse 13. Essas redes de intertextualidade exemplificam o método inovador de João, o qual se desenvolve em novas direções a partir do texto das Escrituras e do uso de modelos míticos conhecidos das culturas do Mediterrâneo Oriental. A narrativa de Apocalipse 13 combina os quatro monstros da visão de Daniel 7 num único monstro, mais as imagens de Leviathan e Behemoth, o que resulta uma interpretação do poder vigente da sua época como a incorporação dos poderes destrutivos na história.

Palavras-chave: Intertextualidade. Daniel 7. Leviathan e Behemoth. Apocalipse 13.

\section{Working with myth - intertextual reading of Daniel 7 and the traditions of Leviathan and Behemoth in Revelation 13}

\section{Abstract}

Revelation of John contains several references to the Jewish Scriptures and other Greek and Roman traditions, which are constantly recreated and re-signified in the development of the book. Considering that a text is both a voice that dialogues with other texts and acts as an echo of the voices of its time, the history of a social group, its values and beliefs, this paper seeks to demonstrate the networks of intertextuality in Revelation 13. These networks of intertextuality exemplify John's innovative method,

* Doutor em Ciências da Religião (Universidade Metodista de São Paulo), doutor em Teoria e História Literária (UNICAMP), professor da Faculdade Unida de Vitória. E-mail: j.adriano1@uol.com.br 
which develops in new directions from the text of Scripture and mythical patterns of Eastern Mediterranean cultures. The narrative of Revelation 13 combines the four monsters of the vision of Daniel 7 in a single monster, plus the images of Leviathan and Behemoth, resulting in an interpretation of the current power of his time as the incorporation of destructive powers into history.

Key-words: Intertextuality. Daniel 7. Leviathan and Behemoth. Revelation 13.

\section{Trabajando con el mito - lectura intertextual de Daniel 7 y de las tradiciones de Leviatán y Behemoth en Apocalipsis 13}

\section{Resumen}

El Apocalipsis de Juan contiene várias referencias a las Escrituras judías y otras tradiciones del mundo grecorromano, las cuales son recriadas y ressignificadas en el desarrollo del libro. Teniendo en cuenta que un texto es una voz que habla a otros textos, sino que también funciona como un eco de las voces de su tiempo, la história de un grupo social, sus valores y creencias, este artículo busca demostrar estas redes intertextualidad en Apocalipsis 13. Estas redes intertextualidad ejemplifican el método innovador de Juan que se desarrolla en nuevas direcciones a partir del texto de la Escritura y el uso de modelos míticos conocidos del area del Mediterráneo oriental. La narrativa Apocalipsis 13 combina los cuatro monstruos de Daniel 7 em un solo monstruo, más las imágenes el Leviatán y Behemoth, lo que resulta em una interpretación del poder dominante de su tiempo como la incorporación de los poderes destructivos de la história.

Palabras clave: Intertextualidad. Daniel 7. Leviatán y Behemoth. Apocalipsis 13.

\section{Introdução}

Quando estudamos as referências às Escrituras judaicas e a outras tradições do mundo greco-romano no Apocalipse de João, nós o lemos a partir da intertextualidade. A intertextualidade, em geral, está ligada à relação entre os textos, os quais nada significam de forma independente. Interpretar um texto, descobrir seu significado e/ou significados, é traçar essas relações. A leitura torna-se um processo de movimentação entre textos. O significado torna-se algo que existe entre um texto e os demais textos aos quais ele se refere e está relacionado, movimentando-se de um texto independente para uma rede de relações textuais. ${ }^{1} \mathrm{~A}$ intertextualidade refere-se também à forma em que um novo texto é criado a partir de metáforas, imagens e símbolos de um texto ou tradição anterior. A interação entre um texto recebido e um novo contexto social traz à existência um novo mundo simbólico e textual. A intertextualidade fornece uma lente hermenêutica por meio da qual se pode ler o novo mundo criado, como

KRISTEVA, Julia. Introdução à semanálise. Trad. Lúcia H. F. Ferraz. São Paulo: Perspectiva, 1974; COMPAGNON, A. O trabalho da citação. Trad. Cleonice P. B. Mourão. Belo Horizonte: Editora. UFMG, 1996. 
ocorre no Apocalipse de João, um livro que utiliza as Escrituras judaicas mais do que qualquer livro do Novo Testamento.

João e os seus destinatários estavam familiarizados com as tradições das Escrituras judaicas, a cosmovisão escatológico-apocalíptica judaica e a cultura greco-romana. Ancorados no conhecimento dessas tradições, os destinatários de Apocalipse relembrariam e entenderiam as diversas referências de Apocalipse ao Pentateuco, Salmos e Profetas, ao Dragão, a mãe e a criança e aos monstros do mar e da terra. ${ }^{2}$ Embora essas redes de intertextualidades tenham um lugar importante na produção de Apocalipse e a sua compreensão seja necessária para o compreendermos como um todo, ${ }^{3}$ o objetivo deste artigo é demonstrar a sua presença em Apocalipse 13, um texto que apresenta duas criaturas chamadas de monstros: o primeiro, "que subia do mar", deriva o seu poder do Dragão, que é o Diabo, Satanás; o segundo, "que subia da terra”, faz uma imagem do primeiro monstro e procura levar as pessoas a adorá-lo. A presença da intertextualidade em Apocalipse 13 exemplifica o método inovador de João, que se desenvolve em novas direções a partir do texto da Escritura e utiliza padrões míticos conhecidos das culturas do Mediterrâneo Oriental. João combina os quatro monstros da visão de Daniel 7 num único monstro, mais as imagens de Leviathan e Behemoth, ricas em simbolismo político, escatológico e cósmico, o que resulta numa interpretação do poder vigente da sua época como a incorporação dos poderes destrutivos na história.

\section{Apocalipse 13:1-18 - os monstros do mar e da terra}

Apocalipse 13 apresenta duas criaturas chamadas de monstros: o primeiro monstro "subia do mar", o segundo "subia da terra". O segundo monstro é subordinado ao primeiro, e o primeiro deriva a sua autoridade do Dragão, apresentado

2 Nos últimos anos, diversos estudos foram dedicados à relação entre o Apocalipse e as Escrituras judaicas, bem como, às tradições mítico-religiosas do mundo greco-romano. Cf. VOGELGESANG, Jeffrey Marshall. The Interpretation of Ezekiel in the Book of Revelation. Cambridge (Massachusetts): Harvard University Press, 1985; RUIZ, See Jean Pierre. Ezekiel in the Apocalypse: The Transformation of Prophetic Language in Revelation 16, 17-19,10. Frankfurt: Peter Lang, 1989; BEALE, G. K. John's use of Old Testament in Revelation. Sheffield: Sheffield Academic Press, 1998, p. 61-62; MOYISE, Steven. The use of the Old Testament in the Book of Revelation. Birmingham: University of Birmingham, 1993; BEALE, G. K. The Book of Revelation. NIGTC. Grand Rapids: William B. E. Publ. Co., 1999, p. 76-99.

3 BEALE, G. K. John's use of Old Testament in Revelation, p. 61-62. 
em Apocalipse 12. ${ }^{4}$ A primeira parte do texto $(13,1-8)$ descreve o monstro que "subia da terra, com dez chifres e sete cabeças; sobre seus chifres, dez diademas, e sobre suas cabeças, nomes de blasfêmia". A segunda parte (13,11-17) descreve o "monstro que subia da terra", com "dois chifres, como de cordeiro, mas falava como Dragão”. Há ainda duas exortações $(13,9-10 ; 13,18)$ dirigidas aos fiéis, as quais concluem as duas partes do texto. As duas unidades estão unidas pelo dito parenético de 13,9-10, que procura alertar os destinatários como eles deveriam agir frente ao monstro que emerge do mar. A exortação de 13,18 convida os destinatários a discernir o número que corresponde ao adversário de Deus. ${ }^{5}$

A fórmula introdutória da visão apocalíptica "Eu vi" ocorre no início das duas partes da narrativa $(13,1.11)$. A referência ao monstro que foi ferido de morte em uma de suas cabeças e voltou à vida está presente nas duas partes do texto $(13,3.12 .14)$. Há uma relação de dependência do segundo monstro em relação ao primeiro. No versículo 14, o monstro da terra exige que os habitantes da terra façam uma imagem em honra ao monstro que foi ferido mortalmente, mas não morreu. O tema adoração está também presente nessas referências $(13,12)$. Outra semelhança entre a primeira e a segunda parte do texto é a afirmação de que o "Dragão" e o "monstro" são adorados por aqueles que não estão inscritos no

4 Apocalipse 12 é uma adaptação do antigo mito do combate que descreve uma batalha entre dois seres divinos e seus aliados pelo domínio universal. Um dos combatentes é, usualmente, um monstro, com frequência um dragão, que representava o caos e a esterilidade, enquanto o seu oponente estava associado com a ordem e a prosperidade. $\mathrm{O}$ conflito consiste numa batalha cósmica, cujo resultado constituirá ou abolirá a ordem na sociedade e a fertilidade na natureza. O mito do combate, em geral, apresenta a seguinte estrutura: 1 - Um casal de dragões - o oponente pode ser um par de dragões ou monstros: (1) marido e esposa, e/ou (2a) irmão e irmã ou (2b) mãe e filho; 2 - Caos e desordem - forças que o oponente representa; 3 - O ataque - o oponente quer (1a) impedir que o deus principal (ou os deuses mais jovens) cheguem ao poder, e/ou (1b) destituí-lo depois de alcançar o poder; 4 - O herói; 5 - A morte do herói; 6 - O reino do dragão - enquanto o deus está morto e confinado ao mundo subterrâneo, o dragão governa destrutivamente: (1) saqueia e satisfaz os seus vários desejos; em particular (2) ataca a esposa ou mãe do deus; 7 - Restabelecimento do herói - (1) a esposa, irmão e/ ou mãe do deus empenha-se em restabelecê-lo (a) pela mágica, ou (b) seduzindo o dragão, ou ( c) lutando ela mesma com o dragão; ou (2) seu filho o ajuda (a) restabelecendo a força perdida do deus, ou (b) assumindo ele mesmo o papel de deus (ou rei); 8 - Batalha renovada e vitória; 9 - Restauração e confirmação da ordem. Cf. COLLINS, Adela. The Combat Myth in the book of Revelation. Missoula, Montana: Scholars Press, 1976, p. 65-71.

5 Diversas exortações de Apocalipse são dirigidas aos seus destinatários. A mensagem dessas exortações exige uma reflexão atenta sobre o que deve ser entendido $(1,3 ; 22,7 ; 22,18-19$; 2,7.11.17.29; 3,6.13.22; 13,9-10;17,9). Cf. Ruiz, Jean Pierre. Eqekiel in the Apokalypse, p. 190-214. 
livro da vida (13,7-8), bem como, a referência à universalidade das consequências da atividade do segundo monstro: "E fez que a todos, pequenos e grandes, ricos e pobres, livres e escravos, lhes fosse dada uma marca sobre sua mão direita ou sobre sua fronte: para que ninguém possa vender nem comprar, a não ser o que tem a marca, o nome do monstro ou o número do seu nome" (13,16-17).

Originalmente, as visões de Apocalipse 12 e 13 não formavam um texto único. ${ }^{6}$ A associação dos dois capítulos, que é uma inovação redacional de João, ocorre pelo uso das expressões "o Dragão lhe deu o seu poder, seu trono e grande autoridade" $(13,2)$ e "adoraram ao Dragão, que deu autoridade ao monstro" $(13,4)$. A expressão "e falava como Dragão", que se refere ao monstro que subia da terra $(13,11)$ pode também ser redacional. Essas inserções redacionais estabelecem a ligação entre Apocalipse 12 e 13. Além disso, Apocalipse 12,18-13,18 é paralelo temporalmente a Apocalipse 12,13-17 e explica com mais detalhes a natureza da perseguição de Satanás. A conjunção "e" (13:1) introduz não a narração das coisas que ocorrerão depois dos eventos descritos em 12,13-17, mas os eventos que acontecem depois da visão do capítulo 12. O escopo histórico do tempo de Apocalipse 13 é paralelo a Apocalipse 12, especialmente Apocalipse 12,6.13-17. O Dragão se coloca "em pé na areia do mar" não porque o ataque à mulher foi frustrado e ele dirige a sua ira contra a sua descendência (12,13-17), mas para convocar os seus auxiliares que executarão sua vontade na terra. Ele os chama das mesmas águas infernais, o mesmo lugar de onde provavelmente originou-se. O capítulo 12 apresenta a ação do Dragão que, de fato, age por intermédio dos monstros, seus servos. ${ }^{7}$ João une essas tradições de modo a fortalecer o argumento que apresenta, isto é, a sociedade na qual os seus destinatários viviam provinha da esfera demoníaca que se opõe a Deus e era hostil à sua fé. João apresenta essa perspectiva àqueles que, entre os seus destinatários, começaram a comprometer a sua fé ao se acomodarem a alguns aspectos da vida na cultura imperial, como a participação em "associações de comércio" e de fidelidade ao imperador (culto imperial). ${ }^{8}$

6 AUNE, David. Revelation 6-16. WBC. Nashville: Thomas Nelson Publishers, 1998, p. 725. BEALE, G. K. The Book of Revelation. The New International Greek Commentary. Grand Rapids: Eerdmans, 1999, p. 681 AUNE, David, Revelation 6-16, p. 725.

8 O culto imperial, alicerçado na ideologia imperial de poder, tornou-se central para a unidade da sociedade romana desde a época do governo de Augustus (29 a.C.-14 d.C.). O termo "culto imperial" é genérico, o fenômeno em si não era homogêneo, mas uma síntese carregada de tensão entre a ideologia do culto helenístico ao soberano, o qual via na pessoa do imperador a epifania de um deus, e as concepções romanas da personalidade extraordinária favorecida pelos deuses, ou seja, os romanos veneravam os poderes transcendentes, os quais, em circunstâncias especiais, podiam manifestar-se em personalidades que se destacavam na sociedade. Nos tempos da república, já no Oriente, honras divinas foram 


\section{O monstro que subia do mar}

$\mathrm{Na}$ narrativa de Apocalipse, o Dragão, "a antiga serpente, o chamado Diabo e também Satanás" (12,9), ataca a mulher e a criança, mas o ataque é frustrado por causa da intervenção de Deus (12,14-18). O Dragão, então, empreende outro ataque por meio de outro personagem: "um monstro que surge do mar", que domina o mundo e tem o poder e a autoridade do Dragão: "Vi, então, um monstro subir do mar, tendo dez chifres e sete cabeças. Sobre seus chifres, dez diademas, e sobre suas cabeças, nomes de blasfêmia. O monstro que vi era semelhante a um leopardo; seus pés, como de urso; sua boca, como boca de leão. O Dragão lhe deu seu poder, seu trono e grande autoridade" $(13,1-2)$. Ele se assemelha ao Dragão, de quem deriva o seu poder (12,3), mas a relação entre eles é mais do que apenas de aparência. O Dragão delega o seu poder ao monstro, o autoriza a agir em seu nome $(13,2)$. Essa forma de delegação de poder mostra paralelos com a maneira na qual Deus e o Cordeiro são apresentados no Apocalipse. O monstro recebe, da parte do Dragão, "poder, trono e autoridade", palavras mencionadas no Apocalipse como atributos de Deus ou do seu Ungido (4,11; 5,12; 7,12; 11,17; $12,10 ; 19,1)$. "Trono" é o lugar de onde Deus governa o mundo $(1,4 ; 3,21 ; 7,15$; $12,5 ; 22,1.3)$ e também o lugar onde Cristo está assentado (3,21; 22,3); além de Deus e Cristo, apenas os 24 Anciãos vestidos de branco estão assentados $(4,4)$. A palavra "autoridade", trazida como atributo de Deus $(16,9)$, de Cristo $(12,10)$, é também mencionada em relação aos servos de Deus $(2,26 ; 6,8 ; 9,3 ; 11,6)$. Apocalipse 12,10 declara que a queda do Dragão foi provocada pelo estabelecimento do poder de Deus e a autoridade de Cristo. Apocalipse 13,2 afirma que o Dragão deu poder, trono e autoridade ao monstro. Aparentemente, o Dragão e o monstro são apresentados como contrapartes de Deus e Cristo. ${ }^{9}$

Além desses paralelos, as imagens do mar que o texto utiliza indicam a natureza do novo personagem, deixando claro que, como o Dragão, o monstro está associado ao caos que ameaça a criação e o povo de Deus. Ele causa es-

tributadas aos generais vitoriosos (culto aos heróis), que sucediam no poder os soberanos helenistas (Pompeu), enquanto em Roma se evitava tratar os dirigentes do Estado como deuses. O culto imperial envolvia um conjunto de ritos religiosos e a sua função principal era a legitimação política da honra do imperador e da sua família. Cf. GRADEL, Gradel, Emperor Worship and Roman Religion. Oxford: Clarendon Press, 2002; PRICE, Simon. Rituals of Power. The Roman imperial cult in Asia Minor. Cambridge: Cambridge University Press, 1984; KLAUCK, Hans-Joseph. O entorno religioso do cristianismo primitivo. Culto aos governantes e imperadores, filosofia e gnose. São Paulo: Edições Loyola, 2011; ZANKER, Paul. The Power of Images in the Age of Augustus. Michigan: The University of Michigan Press, 1988.

9 PEERBOLTE, L. J. L. The Antecedents of Antichrist. A Traditio-Historical Study of Earliest Christian Views on Eschatological Opponents. Leiden: E. J. Brill, 1996, p. 142. 
panto em toda a terra, pois a ferida mortal que recebeu em uma de suas cabeças foi curada: "Uma de suas cabeças estava como que imolada de morte, mas esta ferida de morte foi curada. Toda a terra ficou maravilhada, seguindo atrás do monstro. E adoraram o Dragão, porque deu autoridade ao monstro. Adoraram o monstro, dizendo: 'Quem é igual ao monstro e quem tem poder para lutar contra ele"'? (13,3-4). O monstro recebeu também "uma boca para falar grandes coisas e blasfêmias" (13,5-6). O mundo adora o Dragão e o monstro e reconhece sua incomparável capacidade militar: "E foi-lhe dado fazer guerra contra os santos e vencê-los. Foi-lhe dada autoridade sobre toda tribo, povo língua e nação. Então o adoraram todos os habitantes da terra, os que não têm os seus nomes inscritos no Livro da Vida do Cordeiro, que foi imolado desde a fundação do mundo" (13,7-8).

João apresenta o monstro com dez chifres e sete cabeças, uma descrição cujo paralelo mais significativo são os quatro animais da visão de Daniel 7,1-8:

No primeiro ano de Baltazar, rei da Babilônia, Daniel, estando em seu leito, teve um sonho, e visões se assomaram à sua mente. Ele redigiu o sonho por escrito: Eis o começo da narrativa: Tomou a palavra Daniel dizendo: Eu estava contemplando a minha visão noturna, quando vi os quatro ventos do céu que agitavam o grande mar. E quatro feras monstruosas subiam do mar, uma diferente da outra. A primeira era semelhante um leão com asas de águia. Enquanto eu o contemplava, suas asas lhe foram arrancadas e ele foi erguido da terra e posto de pé sobre suas patas como um ser humano, e um coração humano lhe foi dado. Apareceu a segunda fera, completamente diferente, semelhante a um urso, erguido de um lado e com três costelas na boca, entre os dentes. E a este diziam "Levanta-te, devora muita carne!" depois disso continuando eu a olhar, vi ainda outra fera, semelhante a um leopardo, que trazia sobre os flancos quatro asas de ave; tinha também quatro cabeças e foi-lhe dado o poder. A seguir, ao contemplar essas visões noturnas, vi a quarta fera, terrível, espantosa, e extremamente forte: com enormes dentes de ferro, comia, triturava e calcava aos pés o que restava. Muito diferente das feras que a haviam precedido, tinha esta dez chifres.

João adapta as imagens do texto de Daniel aos seus objetivos retóricos ao unificar num único monstro as características dos quatro animais que Daniel apresenta: leão (v. 4); urso (v. 5), leopardo (v. 6), e "o quarto monstro, terrível e forte, com dentes de ferro (v. 7). ${ }^{10}$ Essa adaptação parece curiosa, caso não consideremos os objetivos retóricos que João procura alcançar. Ele liga o monstro

10 HIEKE, Thomas. "The Reception of Daniel 7 in the Revelation of John", in R. Hays \& Stefan Alkier (orgs.). In: Revelation and the Politics of Apocalyptic Interpretation. Waco, Texas: Baylor University Press, 2012, p. 47-67. 
ao Dragão: “O Dragão lhe deu seu poder, seu trono e grande autoridade" $(13,2)$. João quer que seus destinatários entendam que o monstro está ligado ao Dragão e recebeu o poder das suas forças destrutivas. O Dragão representa uma ameaça cósmica, mas o monstro uma ameaça terrestre. João destaca essa dimensão ao descrevê-la a partir dos animais da visão de Daniel, os quais representam poderes terrenos e políticos que ameaçam a comunidade de fé. Ele procura alertar os seus destinatários de que ele reúne em si todos os perigos dos quatro animais da visão de Daniel, informando-os de que a última manifestação está profundamente enraizada na tradição. Essas imagens se originam essencialmente das visões dos quatro reinos de Daniel 7,2-27. João não as empregou mecanicamente, mas as adaptou aos seus objetivos. Ele não queria apenas ilustrar o desenvolvimento dos eventos históricos, mas caracterizar o poder vigente contemporâneo: ele é claramente um poder demoníaco. ${ }^{11}$

O monstro que subia do mar combina as características dos quatro animais de Daniel 7,1-8 e algumas imagens das cosmologias do antigo Oriente Próximo que falam sobre um monstro mítico, uma serpente marinha, de sete cabeças, que habitava o mar e as águas subterrâneas, chamada Leviathan (Is 27,1), às vezes apresentada em luta contra uma divindade, outras vezes contra Behemoth, um monstro da terra. Leviathan e Behemoth foram criados por Deus, mas seriam preservados até a época messiânica, quando se tornariam alimento no grande banquete escatológico. ${ }^{12}$ Essas tradições a do Leviathan - o monstro das águas - e de Behemoth, o monstro da terra, estão unidas em Apocalipse 13, mas fontes contemporâneas de Apocalipse demonstram que esses dois monstros eram concebidos como um monstro apenas, até serem separados por Deus. ${ }^{13}$ A separação entre Leviathan e

11 ROLOFF. Jürgen. Revelation. Continental Commentary. Trad. John E. Alsup. Minneapolis: Fortress Press, 1993, p. 154-155.

12 HIEKE. "The Reception of Daniel”, 53-55; COLLINS, The Combat Myth, 161-165.

131 Enoque 60,7-8 afirma: "On that day, two monsters will be parted-one, a female named Leviathan, in order to dwell in the abyss of the ocean over the fountains of the water; and (the other), a male called Behemoth, which holds his chest in an invisible desert whose name is dundayin". 4 Esdras 6,49-52 declara: "Then you kept in existence two living creatures; the name of the one you called Behemoth and the name of the other Leviathan. And you separated one from the other, for the seventh part where there are a thousand of mountains; but to Leviathan you have the seventh part, the watery part; and you have kept them to be eaten by whom you wish, and when you wish". 2 Baruque 29,4 assevera: "And Behemoth will reveal itself from its place, and Leviathan will come from the sea, the two great monsters which I created on the fifty day of the creation and which I shall have kept until that time". Cf. CHARLESWORTH, James H. (Org.). The Old Testament Pseudepigrapha. Vol. I. Garden City: DOUBLEDAY, 1983, p. 40, 536, 630. 
Behemoth estava ligada ao surgimento do cosmos, mas agora eles surgem do mar (Ap 13,1) e da terra (Ap 13,11). Trata-se de um ato escatológico que significa a irrupção de forças caóticas sobre a antiga e desgastada criação, antes de um período de restauração e renovação. ${ }^{14}$

João adapta esse mito que falava do surgimento do cosmos ao seu objetivo retórico, escatológico-apocalíptico. Ele utiliza essas imagens da criação como símbolos de entidades que ameaçam os fiéis para mostrar que aquilo que Deus separou na criação está junto novamente, ou seja (na sua forma de falar), em outra tentativa fracassada de derrubar a vontade de Deus. Esses monstros se rebelaram contra Deus, são inimigos do povo de Deus e João não permite que eles sejam simplesmente mortos, mas declara: "O monstro foi aprisionado e, com ele, o falso profeta, o que fazia prodígios diante dele, por intermédio dos quais seduzia os que tinham recebido a marca do monstro e os que adoravam a sua imagem. Os dois foram lançados vivos no lago ardente de fogo e enxofre" $(19,20)$. Eles serão atormentados eternamente por causa de sua rebelião, não serão eliminados e se tornarão alimento de um ou de outro grupo. Essa adaptação do mito atende também ao objetivo retórico de João, que procura convencer seus destinatários do perigo que os ameaça, caso escolham o lado dos oponentes de Deus.

Apocalipse 13,3-4, após mencionar que "uma das cabeças do monstro foi ferida de morte, mas que a ferida foi curada", descreve a reação dos habitantes da terra diante do Dragão e do "monstro que subia do mar": "Uma de suas cabeças estava como que imolada de morte, mas esta ferida de morte foi curada. Toda a terra ficou maravilhada, seguindo atrás do monstro. E adoraram o Dragão, porque deu autoridade ao monstro. Adoraram o monstro, dizendo: 'Quem é igual ao monstro e quem tem poder para lutar contra ele?"'. A menção de que a cabeça do monstro foi ferida de morte é uma referência à lenda do Nero redivivus, que afirmava que Nero retornaria à vida e lutaria contra Roma, como líder de uma grande coalizão de reis do Oriente. ${ }^{15}$ Há ainda duas outras referências à lenda que

14 AUNE, David. Revelation 6-16, p. 728.

15 A lenda do Nero redivivus, preservada nos Oráculos Sibilinos III-V, tem como modelo básico a fuga e o retorno de Nero. Pensava-se que ele não havia morrido, mas fugido para a terra dos Partos. Esperava-se seu retorno, ocasião em que ele se vingaria dos seus inimigos. A lenda se difundiu no mundo romano, especialmente no Oriente, e sua origem pode estar nas circunstâncias vagas da morte de Nero, que nos últimos dias oscilou entre o suicídio e a fuga. Ele também ordenou que um barco estivesse preparado em Óstia e falou sobre sua fuga para os partos, povos com os quais mantinha relações havia algum tempo. No ano 63 d.C., quando a paz entre os dois impérios foi restaurada, Tiridates, irmão de Vologeses I, saudou Nero como imperador e o homenageou como uma emanação de Mitra. Nero, por sua vez, coroou Tiridates como rei da Armênia. Nessa cerimônia, Nero 
envolvem o contexto cultual: a primeira delas afirma que o segundo monstro, que exerce o poder do primeiro, "faz com que toda a terra adore o monstro cuja ferida mortal foi curada" $(13,12)$; a segunda localiza-se num contexto de adoração, pois o segundo monstro faz que toda a terra faça uma imagem do primeiro monstro $(13,14) .{ }^{16} \mathrm{Na}$ tradição judaica, contudo, somente Deus é digno de adoração, e uma característica importante do adversário escatológico encontrada em muitas versões dos escritos judaicos é que ele jamais exige ser adorado como Deus, nem afirma que é Deus. ${ }^{17}$ Esse fato aponta para uma possível reformulação do mito no contexto histórico de Apocalipse. ${ }^{18}$ Além disso, a expressão: "Quem é igual ao monstro" relembra as palavras de blasfêmia e a expressão de arrogância de Daniel 7. No antigo mito do combate, a rebelião era, em geral, expressada por meio de palavras de arrogância e nesse texto o verbo "adorar" (proskunein) é usado em relação ao monstro como expressão do protocolo do culto imperial. ${ }^{19}$

A junção dos quatro monstros de Daniel num único monstro tem seu maior desenvolvimento em 13,5-8, com a apresentação da sua atividade. O monstro tem uma boca que profere palavras arrogantes e de blasfêmia contra Deus, o seu nome

foi honrado como imperador algum houvera sido antes dele e concedeu toda a província da Armênia aos partos. Por causa dessa concessão e do esplendor que recebeu Tiridates, Nero alcançou grande popularidade entre os partos, a qual durou até depois da sua morte. Os partos também tinham alguma razão para desejar o seu retorno e, dado a sua identificação com Mitra, atribuíam-lhe algum poder sobrenatural. O fato de que Nero pensara em fugir para a terra dos partos deu origem à lenda, que apresenta a sua fuga como um fato histórico. A lenda foi facilmente assimilada à expectativa de um rei do Oriente que conquistaria Roma e governaria o mundo. Mesmo ainda em vida, os astrólogos de Nero predisseram que ele deixaria Roma e encontraria um trono no Oriente, especificamente em Jerusalém. Cf. ADRIANO FILHO, José. Oráculos Sibilinos III-V. Judeus no Egito Helenístico e Romano. Identidades Fluidas no Judaísmo Antigo e no Cristianismo Primitivo. São Paulo: FAPESP/ ANABLUME, 2010, p. 137-162.

16 O texto é uma paródia, a qual, como repetição com distância crítica que marca a diferença, assinala uma inversão irônica. Há vários paralelos entre o Cordeiro e o monstro do mar: ambos derivam o seu poder de alguém superior; o Cordeiro comprou para Deus gente de toda a tribo, língua, povos e nações, o monstro do mar exerce autoridade "sobre toda tribo, povo, língua e nação". A ordem dos elementos é mudada e o vocabulário é basicamente o mesmo. O Cordeiro $(5,12)$ e o monstro são adorados $(13,4)$. O Cordeiro é descrito como "imolado" $(5,6)$ e uma das cabeças do monstro do mar "estava como que imolada de morte" (13,3). Cf. ROLOFF, Revelation, p. 155; AUNE, Revelation 6-16, p. 737-740; BEALE, G. The Book of Revelation, p. 687-693.

17 AUNE, David. Revelation 6-16, p. 740.

18 Na tradição do adversário escatológico as pretensões divinas representam um aspecto importante e são encontradas nos escritos judaicos que falam de Antíoco IV Epífanes (Dn 11:36-37), Nero (Or Sib 5:33-34), o rei da Babilônia (Is 14:13-14) e o rei de Tiro (Ez 28:2).

19 AUNE, David. Revelation 6-16, p. 741. 
e o templo, e recebe autoridade por 42 meses. A locução "palavras de blasfêmia" sugere uma referência a Daniel 7,20, que afirma que o pequeno chifre do quarto monstro possui "uma boca que proferia palavras arrogantes". Blasfemar contra Deus é uma característica do adversário escatológico encontrada em muitas passagens da tradição bíblica. Há também blasfêmias proferidas contra o templo e os santos que nele habitam. Além disso, o monstro tem permissão para guerrear contra os santos e vencê-los, sendo-lhe dada "autoridade sobre toda tribo, povo, língua e nação". Por conseguinte, os habitantes da terra que não estão inscritos no livro da vida do Cordeiro adoram o monstro. As consequências provocadas pela atividade desse monstro envolvem todo o mundo, confirmando sua natureza demoníaca. A referência à guerra contra os santos e a vitória sobre eles relembra Daniel 7,21, quando o pequeno chifre faz guerra contra os santos, além de repetir 12,17, onde o Dragão faz guerra aos descendentes da mulher. A influência do monstro é universal, mas o seu poder não deriva dele mesmo. Sua ação é limitada por forças maiores, ou seja, sua influência é aparente. O seu domínio é limitado, com a duração de apenas 42 meses. $^{20}$

A atividade do monstro afeta todas as pessoas e todos aqueles que não têm os seus nomes inscritos no livro da vida do Cordeiro que adoram o monstro do mar, porque ele recebeu a autoridade do Dragão. Em Daniel 7,14 o Filho do homem é adorado por toda a terra ao receber a autoridade de Deus. O verbo “adorar" pode estar relacionado ao episódio de Daniel, quando Nabucodonosor exigiu adoração, e todos os povos, nações e línguas adoraram a estátua de ouro que ele havia levantado. As similaridades entre Daniel 3, 6 e 7 são significativas, pois demonstram que a mesma linguagem é utilizada em Daniel para descrever tanto o falso quanto o verdadeiro culto. Dessa forma, ao descrever a recepção de autoridade do monstro e a recepção de autoridade do Filho do homem, João aplica Daniel 7:14 ao monstro para mostrar que os seus esforços de conquista são uma paródia irônica do triunfo final do Filho do homem. A autoridade do monstro que vence os santos e provoca sua adoração tem origem na mesma fonte que trará o triunfo do Filho do homem. ${ }^{21}$ Além disso, a menção do livro da vida do Cordeiro que foi imolado (13,8), que pode ser uma referência a Daniel 12,1, tem a função de renovar a esperança dos destinatários (Jub 30,22; 1 Enoch 47,3;

20 A determinação do tempo apontado para a atuação do inimigo era bastante conhecida na tradição apocalíptica (Dn 7,25; 8,14; As Is 4,12; Ap El 2,52: Ap 11,2; 12,6; 20,3). Os apocalípticos não abriam mão de porção alguma do poder de Deus. Da perspectiva de João, Deus dá esse poder ao monstro como forma de indicar que todo poder opressor tem seu limite, pois o controle da história lhe pertence.

21 BEALE, G. K. The Book of Revelation, p. 699-700; AUNE, David. Revelation 6-16, p. 746-748. 
14,1; 1 QM 12,2). O livro da vida corresponde a uma metáfora para os santos, cuja salvação foi confirmada pelos nomes que estão escritos no livro da vida do Cordeiro $(3,5 ; 17,8 ; 20,12 ; 21,27)$. Aqueles que se recusam a adorar o monstro e seguem o Cordeiro imolado preservam a sua vida. O monstro, contudo, faz guerra contra os santos, e os vence. A sua imagem será moldada por outro monstro, que subia da terra e procura levar os habitantes da terra a adorá-lo.

Quadro das referências de Daniel 7 retomadas e retrabalhadas em Apocalipse 13:

\begin{tabular}{|l|l|}
\hline \multicolumn{1}{|c|}{ Referências } & \multicolumn{1}{c|}{ Conteúdo } \\
\hline Apocalipse 13,1 // Daniel 7,2-3 & Visão dos monstros do mar \\
\hline Apocalipse 13,2 // Daniel 7,3-6 & Semelhanças e diferenças entre os monstros \\
\hline Apocalipse 13,4 // Daniel 7,6.12 & Comparação entre Deus e o monstro \\
\hline $\begin{array}{l}\text { Apocalipse 13,5a // Daniel } \\
\text { 7,8.25 }\end{array}$ & Boca que fala blasfêmias contra Deus \\
\hline Apocalipse 13,5b // Daniel 7,25 & Duração do reino do adversário de Deus \\
\hline Apocalipse 13,6 // Daniel 7,25 & O monstro profere palavras contra o Altíssimo \\
\hline Apocalipse 13,7a // Daniel 7,21 & $\begin{array}{l}\text { O monstro tem autorização para fazer guerra contra } \\
\text { os santos }\end{array}$ \\
\hline Apocalipse 13,7b // Daniel 7,14 & $\begin{array}{l}\text { O monstro tem poder sobre toda tribo, e língua, e } \\
\text { nação }\end{array}$ \\
\hline
\end{tabular}

\section{O monstro que subia da terra}

$\mathrm{Na}$ segunda parte de Apocalipse 13, João vê outro monstro, "que subia da terra, com dois chifres como de cordeiro, mas falava como Dragão" $(13,1)$, cuja atividade primária é seduzir as pessoas por meio dos sinais que realiza, fazendo que o povo adore o "monstro que subia do mar", que impõe sua vontade a todo o mundo: "Toda a autoridade do primeiro monstro é exercida em sua presença e faz que a terra e todos os que nela habitam adorem o primeiro monstro, do qual foi curada a ferida de morte. Realiza grandes sinais, de modo que até fogo faz descer do céu sobre a terra diante dos homens. Seduz os que habitam sobre a terra por intermédio dos sinais que lhe foi dado fazer diante do monstro, dizendo aos que habitam sobre a terra que façam uma imagem ao monstro, o qual, ainda que ferido pela espada, viveu. E lhe foi dado dar sopro de vida à imagem do monstro, para que a imagem do monstro falasse e fizessem com que fossem mortos os que não adorassem a imagem do monstro. E fez com que a todos, pequenos e grandes, ricos e pobres, livres e escravos, lhes fosse dada uma marca 
sobre a sua mão direita ou sobre a fronte: para que ninguém possa vender nem comprar, a não ser o que tem a marca, o nome do monstro ou o número do seu nome" (13,12-17).

O verbo "fazer" domina a linguagem utilizada na descrição das obras que o segundo monstro realiza em favor do primeiro (13,12.13.14.16-17). ${ }^{22}$ Referido como falso profeta $(16,13 ; 19,20 ; 20,10)$, ele representa a autoridade do primeiro monstro (13:12,16-17). Sua descrição, "com dois chifres como de Cordeiro", contrasta com os dez chifres do monstro do mar e indica sua subordinação a este. Não é apenas o primeiro monstro que é construído a partir de imagens do Dragão e do Cordeiro, mas também o segundo monstro: tem "dois chifres como cordeiro, mas falava como Dragão". ${ }^{23}$ Ele seduz os habitantes da terra (13,13-14) e os exorta a adorar o primeiro monstro (13,14-15). O "monstro "do mar" encerra o simbolismo dos quatro animais de Daniel 7,1-8. O "monstro da terra" é uma novidade na composição de Apocalipse. É uma criação de João, que destaca sua atividade ao apresentá-lo a serviço do primeiro monstro. Sua capacidade de realização deriva do monstro do mar e, como servidor, sua função tem caráter religioso, pois leva os habitantes da terra a adorá-lo. Ele faz isso com o poder que lhe foi outorgado pelo seu chefe, confirmando sua identificação com o poder político vigente.

Um aspecto essencial na atividade dos inimigos escatológicos é a realização de sinais, com o objetivo de seduzir as pessoas. A partir do poder do primeiro monstro, o segundo monstro seduz os habitantes da terra, levando-os a adorar o primeiro monstro. Ao "fazer fogo descer do céu à terra diante de todas as pessoas" $(13,13)$, ele tenta validar sua autoridade profética a partir da tradição do Antigo Testamento, pois esses tipos de sinais ocorrem nas Escrituras no contexto de confirmação da autoridade profética de Moisés diante dos magos egípcios (Êx 4,17.30). Em Daniel 7,37 (LXX), Deus é louvado por fazer grande sinais. O verbo "seduzir", que pertence ao campo semântico do Dragão e dos monstros que recebem poder do Dragão, está relacionado não apenas com o ato de seduzir ou enganar, mas pertence também ao campo do exercício de poder. ${ }^{24}$ "Enganar" é uma característica comum dos oponentes escatológicos (1 En 54,5-6; 68,28). O oponente escatológico promove o culto imperial, provavelmente o motivo que

\footnotetext{
AUNE, David, Revelation 6-16, p. 758-759.

23 "Chifre" significa poder e autoridade na tradição do Antigo Testamento, tanto das nações quanto dos governantes (Zacarias 1:18-21; Ezequiel 29:21; Daniel 8:8).

24 FRIEDRICH, Nestor Paulo. "Manter a identidade e a esperança em meio a um mundo hostil. Desafio da igreja em Tiátira." Religião de Visionários: Apocalíptica e misticismo no Cristianismo primitivo (São Paulo: Loyola, 2005), p. 252.
} 
leva João a denunciá-lo como falso profeta $(13,14 ; 16,13 ; 19,20 ; 20,10)$. A ordem expressa de "fazer uma imagem do monstro" envolve o argumento com o qual o falso profeta incita a adoração à cura milagrosa da cabeça ferida pela espada, mas vive. A palavra imagem $(13,14)$ parece referir-se a Daniel 3, uma narrativa que mostra que o rei Nabucodonosor mandou construir uma estátua de ouro, erguendo-a num lugar público para que todos a adorassem, mas quem se negasse a fazê-lo seria punido com a morte.

O monstro que subia da terra tem também autorização para dar espírito à imagem do primeiro monstro, para que ele falasse, ${ }^{25}$ e os sinais de fogo que faz cair do céu diante dos homens relembram as demonstrações proféticas de Elias (1 Rs 18,38; 2 Rs 1,10-14). Essa tradição de grandes sinais realizados no contexto da autoridade profética, de forma negativa, era bem difundida na tradição cristã (2 Ts 2,9; Mc 13,22; 2 Pe 2,1). O monstro se apresenta como anunciador da verdade expressa na identificação com o Cordeiro, mas é, de fato, um falso profeta. Entretanto, apesar de ser um falso profeta, é uma figura subordinada e tem um papel importante no sistema imperial. É subordinado no sentido de que sua autoridade deriva do primeiro monstro e porque promove o seu culto, sendo responsável por organizar e reforçar a obediência.

Com sua representação, portanto, João apresenta outro aspecto da sociedade imperial: a autoridade demoníaca das elites locais, que pertenciam às famílias ricas e proeminentes e colaboravam com Roma. O governo e a piedade não estavam separados, nem tampouco os líderes dessas atividades compunham grupos distintos. O monstro da terra espelha o monstro do mar mostrado antes, da mesma forma que a estátua do imperador o espelha. O monstro da terra também exige que adoração e culto sejam oferecidos ao primeiro monstro. Nesse caso, se a adoração do monstro e da sua imagem estiver ligada ao culto imperial (culto ao imperador), então um conflito fundamental do livro centra-se na verdadeira adoração a Deus e a Cristo versus a falsa adoração ao imperador e ao seu culto. ${ }^{26}$ A apresentação do monstro da terra lembra também as famílias governantes da Ásia Menor que controlavam o ofício político e os diversos tipos de sacerdócio. Essas famílias e a população geral entusiasticamente apoiavam e ajudavam a expandir o culto imperial. Elas conduziam sacrifícios, festivais, construíam templos, votavam honrarias como parte de seus deveres cívicos e mobilizavam as massas

\footnotetext{
25 SHERRER, S. Signs and Wonders in the Imperial Cult. JBL 103, 1974, p. 599-610.

26 THOMPSON, Leonard L. The book of Revelation. Apocalypse and Empire. New York/Oxford: Oxford University Press, 1990, p. 164.
} 
em apoio ao imperador. O poder romano distante governava, enquanto as elites locais colaboravam na pacificação e estabilização de suas regiões. ${ }^{27}$

Resumindo, Apocalipse 13 é uma releitura de textos e tradições que já tinham sentido para grupos sociais judaicos e que eram parte da sua memória. Esses textos e tradições foram reorganizados pelos seguidores de Jesus, o Messias, representados no Apocalipse, conformando novos signos, novas linguagens e novos textos. Nesse sentido, a representação do poder vigente, e do culto imperial em particular, de Apocalipse 13 exemplifica o método inovador de João, que se desenvolve em novas direções a partir do texto da Escritura e do uso de padrões míticos conhecidos das culturas do Mediterrâneo Oriental. João combina os quatro animais da visão de Daniel 7 num único monstro com as imagens do Leviathan e Behemoth, ricas em simbolismo político, escatológico e cósmico, o que resulta numa interpretação do poder vigente da sua época como a incorporação dos poderes destrutivos na história.

Nessa estrutura de pensamento, o poder político vigente é apresentado como demoníaco, como uma composição de todos os impérios tirânicos que combinam as características destrutivas de seus predecessores. $\mathrm{O}$ monstro do mar recebe o seu poder e autoridade do Dragão. Havia formas demoníacas e divinas no mundo de João, mas o que estava em jogo era a forma como essas forças se legitimavam. Essas formas eram legitimadas pelo culto. João, porém, apresenta o contraste entre elas: a autoridade de Deus e do Cordeiro era própria, pois estava fundamentada na natureza de Deus como criador e nas ações de Jesus como redentor. A autoridade do Dragão e do monstro do mar baseia-se na sedução e na força. O Dragão é identificado com Satanás e apresentado como o "sedutor de toda a terra". A atividade primária do monstro da terra é seduzir, o que é acompanhado pelos grandes sinais que realiza, levando o povo a adorar o monstro do mar. João, portanto, retrata de forma razoavelmente acurada uma das pressuposições básicas do culto imperial: a autoridade romana se ancorava na habilidade de subjugar os inimigos, e que não era possível nem se deveria resistir ao poder imperial romano. ${ }^{28}$

A oposição à comunidade fiel que o texto apresenta está também em continuidade com o antagonismo que sempre desafiou o povo de Deus na história bíblica. O uso da imagem do Dragão indica que o novo inimigo recebeu o poder do próprio Satanás. João destaca também a dimensão religiosa da atividade desse

FRISEN, Steven J. Imperial Cults and the Apocalypse of John: Reading Revelation in the Ruins. Oxford: Oxford University Press, 2001, p. 202-203. PRICE, Simon. Rituals and Power, p. 99-101.

28 FRIESEN, Steven J. Imperial Cults and the Apocalypse of John, 175-176, 201-202. 
novo inimigo. Ele confronta os seus destinatários com o que pode significar lealdade ao poder vigente ou até mesmo a crença de que a participação na sociedade era religiosa ou espiritualmente neutra. Qualquer exigência de fidelidade ao poder vigente representa um desafio à soberania de Deus e uma ameaça à fé. A fidelidade ao poder vigente, não importa suas intenções e amplitude de escopo, é um monstro insidioso que coloca em perigo o destino de todos os que declaram sua fidelidade ao poder vigente. João revela o tempo presente como o ataque final à comunidade de fé e espera que coisas mais difíceis ocorram nos últimos dias, mas o Apocalipse não está marcado pela desesperança: "A comunidade cristã canta o poder de Deus e a soberania de Cristo. Ao recordar, continuamente, o culto, ao inserir o poder de Deus e de Cristo, cantado no culto em hinos, em contradição direta com o poder vigente, João indica o culto como um lugar de aprendizagem: a confissão de fé na soberania de Deus e de Cristo deve ser entendida como testemunho para o mundo, mas, ao mesmo tempo, como protesto contra toda a soberania que se lhe opõe". ${ }^{29}$

\section{Referências}

ADRIANO FILHO, José. Oráculos Sibilinos III-V. Judeus no Egito Helenístico e Romano. Identidades Fluidas no Judaísmo Antigo e no Cristianismo Primitivo. São Paulo: FAPESP/ANABLUME, 2010, p. 137-162.

AUNE, David. Revelation 6-16. WBC. Nashville: Thomas Nelson Publishers, 1998.

BEALE, G. K. John's use of Old Testament in Revelation. Sheffield: Sheffield Academic Press, 1998.

BEALE, G. K. The Book of Revelation. NIGTC. Grand Rapids: William B. Eerdmans Publ. Co., 1999, p. 76-99.

Bíblia de Jerusalém. São Paulo: Paulus, 5a impressão, 2008.

CHARLESWORTH, James H. (Org.). The Old Testament Pseudepigrapha. Vol. I. Garden City: Doubleday, 1983.

COLLINS, Adela Y. The Combat Myth in the book of Revelation. Missoula (Montana): Scholars Press, 1976.

COMPAGNON, A. O trabalho da citação. Trad. Cleonice P. B. Mourão. Belo Horizonte: Ed. UFMG, 1996.

FRIEDRICH, Nestor Paulo. "Manter a identidade e a esperança em meio a um mundo hostil. Desafio da igreja em Tiátira.” Religião de Visionários: Apocalíptica e misticismo no Cristianismo primitivo (São Paulo: Loyola, 2005), 233-262.

29 WENGST, Klaus. Pax Romana. Pretensão e Realidade. Experiências e percepções da paz em Jesus e no cristianismo primitivo. São Paulo: Paulinas, 1991, p. 197-198. 
Trabalhando com o mito - leitura intertextual de Daniel 7157

e das tradições de Leviathan e Behemoth em Apocalipse 13

FRISEN, Steven J. Imperial Cults and the Apocalypse of John: Reading Revelation in the Ruins. Oxford: Oxford University Press, 2001.

GRADEL, Gradel. Emperor Worship and Roman Religion. Oxford: Clarendon Press, 2002.

HIEKE, Thomas. 'The Reception of Daniel 7 in the Revelation of John', in R. Hays \& Stefan Alkier (Orgs.). In: Revelation and the Politics of Apocalyptic Interpretation. Waco, Texas: Baylor University Press, 2012, p. 47-67.

KLAUCK, Hans-Joseph. O entorno religioso do cristianismo primitivo. Culto aos governantes e imperadores, filosofia e gnose. São Paulo: Edições Loyola, 2011.

KRISTEVA, Julia. Introdução à semanálise. Trad. Lúcia Helena França Ferraz. São Paulo: Perspectiva, 1974.

MOYISE, Steven. The use of the Old Testament in the Book of Revelation. Tese de Doutorado. Birmingham: University of Birmingham, 1993.

PEERBolte, L. J. L. The Antecedents of Antichrist. A Traditio-Historical Study of Earliest Christian Views on Eschatological Opponents. Leiden: E. J. Brill, 1996.

PRICE, Simon. Rituals of Power. The Roman imperial cult in Asia Minor. Cambridge: Cambridge University Press, 1984.

ROLOFF, Jürgen. Revelation. Continental Commentary. Trad. John E. Alsup. Minneapolis: Fortress Press, 1993, p. 154-155.

RUIZ, See Jean Pierre. Ezekiel in the Apocalypse: The Transformation of Prophetic Language in Revelation 16, 17-19, 10. Frankfurt: Peter Lang, 1989.

SHERRER, S. Signs and Wonders in the Imperial Cult. JBL 103, 1974, p. 599-610.

THOMPSON, Leonard L. The book of Revelation. Apocalypse and Empire. New York/ Oxford: Oxford University Press, 1990.

VOGELGESANG, Jeffrey Marshall. The Interpretation of Ezekiel in the Book of Revelation. Tese de doutorado. Cambridge (Massachusetts): Harvard University Press, 1985.

WENGST, Klaus. Pax Romana. Pretensão e Realidade. Experiências e percepções da paz em Jesus e no cristianismo primitivo. São Paulo: Paulinas, 1991.

ZANKER, Paul. The Power of Images in the Age of Augustus. Michigan: The University of Michigan Press, 1988.

Submetido em: 3-4-2017

Aceito em: 16-4-2018 